\title{
ФІЛОСОФСЬКІ МОТИВИ У ТРИПТИХУ «ДОЛЯ», «МУЗА», «СЛАВА» І МЕДИТАЦІї «НЕ НАРІКАЮ Я НА БОГА...» Т.Г. ШЕВЧЕНКА
}

\section{В.Г. Терещенко}

Поширене уявлення про те, що Шевченко - поет соціальної теми, спонукало дослідників, які вивчали його творчість, зосереджувати увагу переважно на ідеях революційної боротьби, гуманізму, патріотизму, інтернаціоналізму. Серед величезної кількості шевченкознавчих досліджень дуже мало таких, які б розглядали філософічність, психологізм, інтелектуалізм поезії Шевченка [1, с. 225-236].

Філософська проблематика в його поетичних творах не вичерпується окремими творами на ту чи іншу філософську тему. Таких у нього небагато, оскільки предметом художнього втілення для поета була реальна історична дійсність, життя людини як таке, а не абстрактна філософська ідея. Коли ми говоримо про філософські мотиви в поезії Шевченка, то маємо на увазі такі твори чи окремі фрагменти з них, в яких містяться глибокі роздуми про історичний прогрес, закономірності людського буття i буття природи, i де художні картини й узагальнення позначені філософським баченням світу.

Цікаві думки і спостереження про лірику Шевченка, її філософське спрямування містить монографія Є. Шабліовського «Народ і слово Шевченка», в якій автор звернув увагу на те, що «характерною рисою Шевченкової лірики $€$ іï виразне інтелектуальне начало; вона сповнена найпекучіших роздумів, рефлексій. Вона пройнята невгасимою жадобою пізнання світу, життя, людей, майбутнього. Звідси - голос мудрого судження, сміливого рішення» $[9$, с. 206].

Окремі судження про лірику Шевченка знаходимо у монографії Юрія Івакіна «Поезія Шевченка періоду заслання». В ній є не тільки глибокий аналіз ряду «лірико-філософських медитацій», а й зроблено важливі 
висновки про особливості їх стилю- аналітичність, автологічність, психологізм.

В. Мовчанюк у своїй монографії «Медитативна лірика Т.Г.Шевченка» дослідив поетичне мислення та світовідчуття Шевченка, еволюцію його творчої самосвідомості; становлення поетичних форм. Медитативна лірика Кобзаря в монографії розглянута на тлі жанрово-стильового розвитку європейської поезії. «Як поет і мислитель, як особистість, що глибоко переймалася моральними проблемами епохи, долею людини, Шевченко найбільш повно і яскраво виявив себе у медитативній ліриці» $[4$, c.5]. В. Мовчанюк зазначає, що характерною особливістю медитативної лірики як форми поетичного самовираження $\epsilon$ її здатність відображати безпосередній процес авторської свідомості, почуття, думки, емоції, переживання, викликані тим чи іншим явищем життя.

Творчість Шевченка як філософського поета розглядав Л. Плющ. Виходячи $з$ того, що «поетична постава філософських проблем та їх розв'язання суттєво відрізняються від наукової, професійно-філософської» [6, c.8], автор, зокрема, дослідив такий засіб втілення філософсько-поетичного змісту, як «готові кліше народних пісень і балад». Принципово нові можливості для подальших студій відкривають і праці Г. Грабовича: низка статей у різних виданнях, а також підсумкова монографія «Шевченко як міфотворець».

В дослідженні філософських аспектів поезії Т. Шевченка нас цікавить не тільки ㄲï суб'єкт як носій певного мислення і світопереживання, а й його сприйняття об'єкта. Авторське бачення і осмислення світу, людини, митця у досліджуваних поезіях є для нас головним. Цим визначаються параметри мислення поета. Розглядаючи характерні особливості поетичного мислення автора, слід звернути увагу і на способи образного мислення, втілення об'єктів дійсності в поетичному світі письменника. «Людина і світ, особа і суспільство, людська особистість та історичний час - це питання, висвітлення яких має кардинальне значення для розуміння творчості митця...» [8, с.4]. Дослідження філософських мотивів у ліриці Шевченка дає цікавий матеріал для глибокого осмислення творчої індивідуальності поета, його буттєвої і творчої самосвідомості.

Триптих «Доля», Муза», «Слава» з'явився на початку нового етапу творчості Т.Шевченка і став цілком закономірним явищем для тодішнього психологічного і творчого стану поета. Пройшовши випробовування засланням, він набув нового психологічного і життєвого досвіду, ще міцніше утвердився на своїх ідейних і морально-етичних позиціях, по-новому почав оцінювати свій життєвий і творчий шлях. «Але зміст триптиха сягає далеко за рамки психологічної самооцінки - перед нами оригінальна концепція творчо-психологічного буття митця, твір філософського змісту $[4$, с.98]. Запис Шевченка у щоденнику від 9 лютого 1858 року свід- 
чить, що триптих був створений «без малейшего усилия» [11, с. 239]. Він має струнку композицію - складається з трьох частин, кожна з яких має свою, проголошену у назві тему, що дає підстави розглядати твір як ідейно-художню цілість, в основу якої покладено певну конкретну світоглядну концепцію. Поетична думка розвивається тут логічно і послідовно. Поет свідомо поєднує три різні точки зору на одну проблему, у якій сконцентрована його буттєва і творча самосвідомість як митця і людини. Трактування Шевченком власної долі в триптиху порівняно з творами попередніх періодів істотно відрізняється.

Є.Ненадкевич відзначив, що «... триптих воднораз дає і щось посутньо нове, по-новому розв'язує проблеми, які ставилися в попередній поезії. Шевченко зовсім інакше, оптимістично усвідомлює свою долю, що на неї часами складає такі гіркі, пристрасні жалі у ліриці з років заслання» [5, с. 42]. Але, як нам здається, відмінність не лише в оптимістичному усвідомленні долі. Важливо те, що у триптиху відбився новий психологічний статус поета, а головне - висловлена потреба по-новому поглянути на прожиті роки, осмислити моральний досвід свого життя.

У раніше написаних творах Шевченка також порушувалися проблеми буття митця, але здебільшого психологічні її аспекти. В даному разі поет намагається розв'язати її у філософському плані. Буття митця як проблема умовно ділиться ним на три категорії- життєвий шлях, поезія (муза) і слава, тобто відгомін, оцінка праці. Кожен із віршів триптиха художньо завершений і може розглядатися як самостійний, але ідеї, що представлені у них, взаємодоповнюють одна одну і цілісно виражають художню індивідуальність поета, його буттєву і творчу сутність.

Вірш «Доля» є ядром авторської концепції митця, якого Шевченко трактує як нерозривну єдність поета-людини і поета-творця. У вірші «Доля» йдеться не лише про життєву долю поета, а й про долю творчу. Їх поет не розділяє:

Ми не лукавили з тобою,

Ми просто йшли; у нас нема

Зерна неправди за собою. [10, с. 583$]$

У цих рядках йдеться не тільки про моральні життєві принципи, а й принципи своєї творчості в цілому. У кінці вірша говориться також і про славу, яку поет конкретизує поняттям «заповідь» («А слава - заповідь моя»), під якою розуміє результат творчого шляху, а отже, і заповіт сучасникам і нащадкам. До того ж тут відсутня іронія, з якою говориться у вірші «Слава». Отже, у першому вірші триптиха йдеться про всі три категорії- Долю, Музу, Славу, хоч і в дуже стислому виразі.

Важливу роль у творенні поетичної логіки вірша «Доля» відіграє образ долі, в якому, по суті, умовно сфокусовано об'єкт роздумів поета. 
Образ долі має народно-символічну першооснову, що особливо відчутно на початку вірша, де доля виступає як спрямовуюче начало, невидима субстанція, що ніби повинна піклуватися про людину, вести її в житті. 3 рядка «Ми не лукавили з тобою» у вірші суттєво змінюється зміст. Якщо на початку твору поет говорить про свою життєву дорогу як зумовлену долею:

... Ти взяла

мене, маленького, за руку

I в школу хлопця одвела

До п'яного дяка в науку.

«Учися, серденько, колись

3 нас будуть люде», - ти сказала

А я й послухав, і учивсь,

І вивчився. . . [10, с. 583], -

то далі шлях цей трактується як результат свідомих моральних орієнтирів і критеріїв. Отже, образ долі у вірші не одноплановий. Він еволюціонує від традиційної народної символіки в значенні фатуму до розуміння життєвого шляху як результату свідомого морального вибору і цілеспрямованого відстоювання своїх ідеалів. Категорія долі тут-поняття поетичне, образне, воно є тією традиційною символічною фігурою, до якої звернений ліричний монолог автора. Разом з тим - це образ-поняття, що дає можливість широкого філософсько-поетичного узагальнення, цілісного концептуального погляду на людське життя.

У другій частині триптиху, вірші «Муза», Шевченко осмислює свою поезію і як психологічний фактор свого духовного життя, і як явище суспільне, що виражається через його ідейно-естетичний ідеал. Наявні психологічні мотиви підкреслені автобіографічним контекстом:

Мене ти всюди доглядала.

В степу, безлюдному степу,

В далекій неволі,

Ти сіяла, пишалася,

Як квіточка в полі!

Із казарми нечистої

Чистою святою

Пташечкою вилетіла

I понадо мною

Полинула... [10, с. 584]

Ці мотиви складають основу ліричного сюжету поезії, об'єкт якої майстерно втілений у багатоплановий образ музи. У перших двох рядках: 
А ти, пречистая, святая,

Ти, сестро Феба, молодая! [10, с.583]

поет виступає традиційно (як у романтичній поезії), акцентуючи увагу на небесному образі молодої музи. Але далі муза персоніфікується в образ матері, набуває суто шевченківських рис:

Мене ти в пелену взяла

І геть у поле віднесла.

I на могилі серед поля,

Як тую волю на роздоллі,

Туманом сивим сповила.

I колихала, і співала,

I чари діяла... [10, с. 583]

Поет, як і у вірші «Доля», прагне осмислити значення поезії в своєму житті і одночасно виразити суть власної творчості. У звернених до Музи рядках, що звучать як молитва, виразились його громадянська позиція і принцип творчості:

Не покидай мене. Вночі,

I вдень, і ввечері, і рано

Витай за мною... .і учи,

Учи неложними устами

Сказати правду. [10, с.584]

Ідея правди як основи буття художника, проголошена у вірші «Доля» і повторно підкреслена в «Музі», безперечно, має концептуальну основу. В цих творах знайшла яскраве художнє вираження творча самосвідомість Шевченка, сформульовано основний принцип його естетичного кредо.

Глибиною поетичного мислення виділяється і останній вірш триптиха «Слава». Він є своєрідним підсумком, критичним поглядом на сказане в двох попередніх частинах триптиха. Роздуми про власну славу переходять тут в більш загальний, філософський план. Мова йде про істинність слави. Мотив правди, що прозвучав у «Долі» і «Музі», набуває тут подальшого розвитку. 3 іронією автор застерігає себе від самозвеличування, наголошуючи на тому, що говорити про славу треба диференційовано, - розрізняючи славу справжню і славу фальшиву. У вірші «Слава» проявився яскравий мистецький інтелект поета, здатність аналізувати філософські, морально-психологічні і суспільні явища. Славу він розглядає як явище суспільно-психологічне. Поет «осуджує не славу взагалі, адже це абстрактне поняття, а той людський загал, в очах якого слава-привілей коронованих злодіїв» $[1$, с. 242], критикуючи тим самим моральні 
ідеали тогочасного суспільства. Свою думку поет ілюструє конкретними прикладами з історії:

А ти, задрипанко, шинкарко,

Перекупко п'яна!

Де ти в ката забарилась

3 своїми лучами?

У Версалі над злодієм

Набор розпустила? [10, с. 585]

...

I 3 п'яними кесарями

По шинках хилялась,

А надто 3 тим Миколою

У Севастополі [10, с. 583],-

тут він згадує славу Наполеона і Миколи I, надаючи своїм роздумам й політичного підтексту. Про славу «кесарів» поет говорить з гнівом, навіть у лайливому тоні.

Аналізуючи індивідуально-психологічний аспект слави, поет виходить із оцінки особистого відношення до власної слави. В основу образу автор поклав індивідуальний досвід, надає йому загального змісту, показує не тільки себе, а людину взагалі. Через особисті сумніви Шевченко аналізує буттєво-психологічний фактор моральної поведінки людини.

Такою ж, тематично близькою до триптиху, є медитація «Не нарікаю я на бога...» (1860). Але якщо триптих «Доля», «Муза», «Слава»-своєрідне підведення підсумків пройденого шляху, то вірш «Не нарікаю я на бога...» більш спрямований у майбутнє, хоч в основі його також лежить аналіз власного духовного буття, оцінка долі. Роздуми, предметом яких стає знову ж таки творча робота митця, переливаючись у поетичні образи, набувають філософського звучання. Структурно вірш об'єднується образом автора як ліричним суб'єктом. Цей образ має і конкретно біографічний контекст і загальнолюдський. В ньому відбиваються роздуми над смислом життя, над загадкою долі самого поета, яка веде його через важкі дороги випробувань, боротьби, сумнівів до того моменту, коли можна зробити висновок:

Не нарікаю я на бога,

Не нарікаю ні на кого. [10, с. 669$]$

«Не нарікаю я на бога... », тобто до усвідомлення певності, що нива, на якій поет трудився, засіваючи її словом, буде врожайна - «добрі жнива колись то будуть». 
Філософічність медитації закладена в образі ліричного суб'єкта твору, тобто в образі людини, пафос морального життя якої-у боротьбі за високий смисл життя. Вірш ніби продовжує ту провідну філософську тему «нащо живеш?», розгорнуту у триптиху «Доля», «Муза», «Слава». Можливо, саме в цих творах намітився головний філософський акцент всього доробку Шевченка. Філософське, інтелектуальне начало його лірики реалізується не у формі риторичних сентенцій, а в образі людини, що постає з його поетичних творів, з її духовного світу, характеру їі мислення і світопереживання, морально-етичного ідеалу.

Говорячи про філософське начало в цьому творі, слід мати на увазі і те інтелектуально-асоціативне багатство, закладене в інших його образах, їх взаємодію. Характерним є символічний образ ниви, що виражає емоційний зміст поетичного переживання:

Орися ж ти, моя ниво,

Долом та горою!

Та засійся, чорна ниво,

Волею ясною!

Орися ж ти, розвернися,

Полем розстелися. [10, с.669]

Нива - символ не тільки поезії Шевченка, а й широкого поля, на якому буде трудитися весь народ:

Вийдуть люде жито жати...

Веселії жнива!.. [10, с. 670$]$

Шевченко роздумує про долю своєї музи, поетичної праці і ширше про творців національної культури, закликаючи на цю ниву нових трудівників:

Розвернися ж, розстелися ж,

Убогая ниво!!! [10, с.670]

Таким чином, в образі ниви, на яку «вийдуть люде жито жати» метафорично втілено авторське уявлення про призначення своєї поезії, розкрито оригінальне художнє філософське бачення культурного творення, суб'єктами якого є народ і митець.

Підсумовуючи, можна сказати, що філософічність розглянутих поезій Шевченка зв'язана з його інтелектуально-психологічним досвідом, його інтуїтивним проникненням у таємниці людського життя, добрим знанням етичних ідеалів, побутової філософії народу, його життєвої мудрості. «Шевченко як творець самого типу національної культури, де ідея 
національного буття народу піднесена до філософського рівня, мав вирішальний вплив на подальший характер української філософсько-поетичної традиції» [7, с.98].

\section{1 Бібліографія}

[1] Івакін Ю.О. Коментар до «Кобзаря» Шевченка. Поезії 1847-1861 pp. - K., 1968.

[2] Івакін Ю.О. Нотатки шевченкознавця. - К., 1986.

[3] Лесин В.М., Пулинець О.О. Словник літературознавчих термінів. K., 1971.

[4] Мовчанюк В.П. Медитативна лірика Т.Г.Шевченка. - К., 1993.

[5] Ненадкевич Є.О. Творчість Т.Г.Шевченка після заслання (18571861). - K., 1966.

[6] Плющ Л. «Причинна» і деякі аспекти філософії Шевченка // Сучасність. - 1979. - №3.

[7] Соловей Е.С. Українська філософська лірика. - К., 1999.

[8] Ткачук М.П. Естетична концепція людини в «Енеїді» Івана Котляревського. - К., 1995.

[9] Шабліовський Є.С. Народ і слово Шевченка. - К., 1961.

[10] Шевченко Т.Г. Зібрання творів: У 3 т. - К., 1963. - Т. 1.

[11] Шевченко Т.Г. Автобиография. Дневник. - К., 1988. 